\title{
Households Credits, Financial Intermediation and Monetary Policies
}

\author{
Cécile Bastidon \\ LEAD, Université de Toulon, Toulon, France \\ Email: bastidon@univ-tln.fr
}

Received 11 July 2014; revised 2 August 2014; accepted 1 September 2014

Copyright (C) 2014 by author and Scientific Research Publishing Inc.

This work is licensed under the Creative Commons Attribution International License (CC BY). http://creativecommons.org/licenses/by/4.0/

(c) (i) Open Access

\begin{abstract}
This paper develops a theoretical model of financial intermediation with three original characteristics. Firstly, all sectors are taken into account within total outstanding credits, including households. Secondly, in periods of high financial strains, the relationship between prices and funding supply volumes may be non-monotonic. Finally, the occurrence of interbank credit rationing results in other sectors' funding rationing in credit and securities markets. The central bank conducts a non-standard type monetary policy. We show that the characteristics of financial intermediation then determine the magnitude of transmission of a shock on households financing costs and the content of the resulting monetary policy.
\end{abstract}

\section{Keywords}

\section{Financial Intermediation, Households Credits, Non-Standard Monetary Policies}

\section{Introduction}

For two decades, monetary policies have undergone profound changes along with the characteristics of financial intermediation. Although the first observation is the subject of many recent works, the second is less frequently considered. Theoretical models of financial intermediation typically operate on the assumption of simple intermediation chains: firms have financing needs and households have financing capacities. The risks associated with those simple chains result from the necessary transformation of "illiquid assets into liquid liabilities" as in Diamond \& Dybvig. Recent theoretical models are still based on this assumption: the interbank credit rationing model of [1] or the endogenous liquidation cost model of [2] describe a liquidity shock resulting from a run of households on demand deposits, while loans are granted only to firms. These mechanisms are common in DSGE models, explicitly taking into account the intermediation activity: demand deposits and direct holding of riskless government securities are perfect substitutes [3]; household deposits finance business loans [4]. 
The current features of intermediation are far from this scheme. Households credits in particular are an increasing part of both banks' balance sheets and total outstanding credits [5]. These households credits portfolios generate a specific double risk. On the one hand, defaults on households credits are sensitive to the output gap and interest rate risk [6]. On the other hand, the massive occurrence of defaults is more frequent when banks do not hold credit portfolios [7]. This occurrence generates simultaneous risk premium and liquidity shocks in complex assets markets, which are transmitted to the interbank market and then the whole financing system [8].

In this context, we propose a theoretical model of financial intermediation with three original characteristics. Firstly, all sectors are taken into account within total outstanding credits, including households. Secondly, in periods of high financial strains, the relationship between prices and funding supply volumes may be non-monotonic. Thirdly and finally, the occurrence of interbank credit rationing results in other sectors funding rationing in credit and securities markets. The central bank conducts a non-standard type monetary policy. We show that the characteristics of financial intermediation then determine the magnitude of transmission of a shock on households financing costs and the content of the resulting monetary policy. The remainder of the paper is organized as follows: Section 2 describes the stylized facts; the survey is the subject of Section 3; the model is presented in Sections 4 (environment and actors) and 5 (shock on households credits defaults).

\section{Financial Intermediation: Stylized Facts}

A key feature of our model of financial intermediation is that households credits are taken into account. In fact, banks credits to non-financial agents represent, for instance, about one-third of total banks assets in France, onehalf in Germany and 60\% in the United States (Figure 1(b), Figure 2(b) and Figure 3(b)). The comparison between total households credits and total outstanding credits to non-financial agents in bank balance sheets (Figure 1(a), Figure 2(a), Figure 3(a)) is striking: while the former is about one-half of the latter in France and Germany, it is more than $160 \%$ in the United States in 2007. As regards the composition of households credits portfolios by term (Figure 1(c), Figure 2(c), Figure 3(c)) and destination (Figure 1(d), Figure 2(d), Figure 3(d)), there are also two distinct schemes. In the "European" scheme, households credits portfolios are less sen-

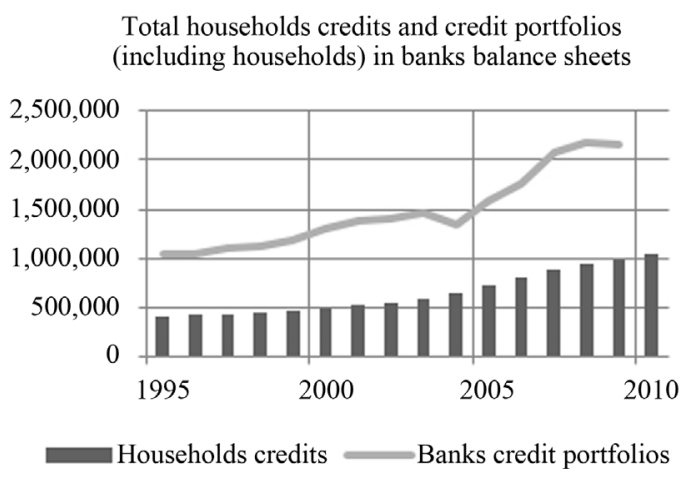

(a)

Households credits, by term (total outstanding volume)

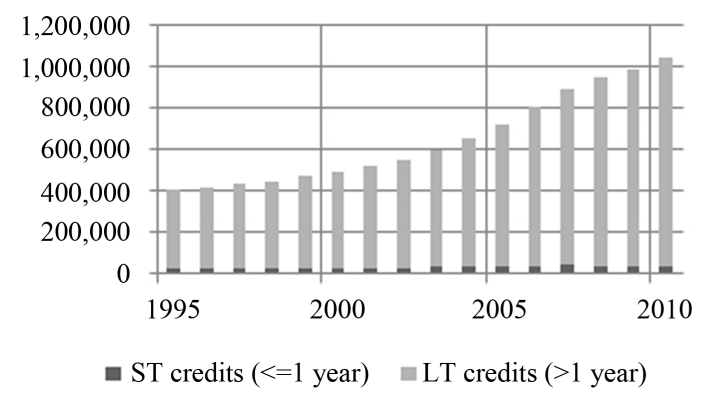

(c)

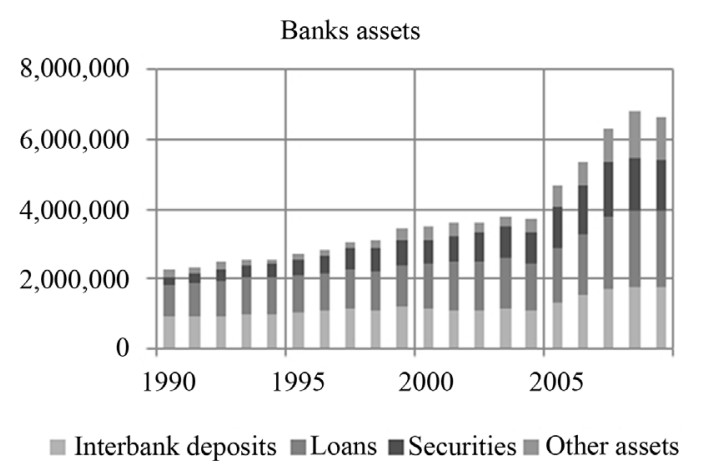

(b)

LT households credits, by purpose (total outstanding volume)

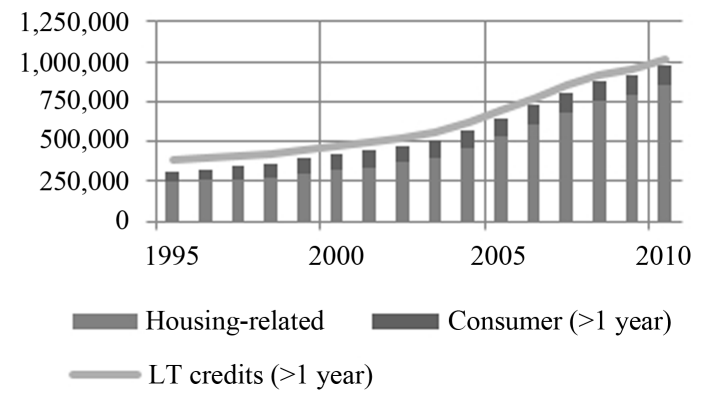

(d)

Figure 1. France: households credits and banking intermediation (millions EUR, source OCDE). 
Total households credits and credit portfolios (including households) in banks balance sheets

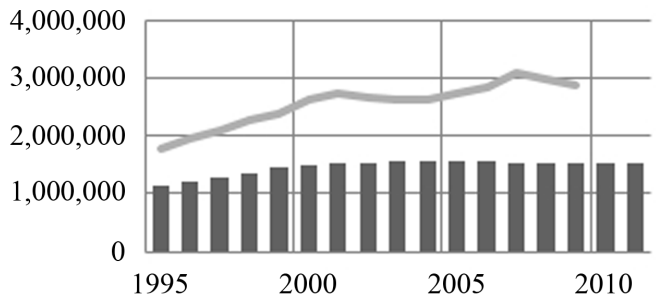

Households credits $\longrightarrow$ Banks credit portfolios

(a)

Households credits, by term (total outstanding volume)

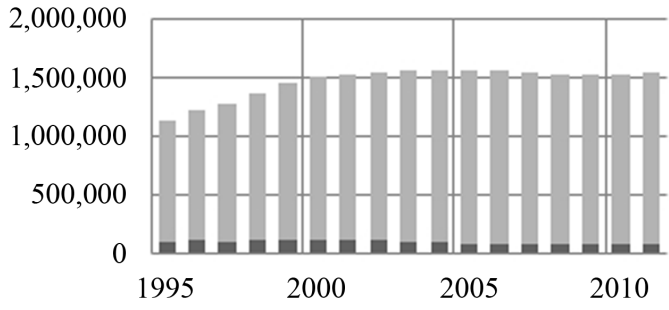

घT credits $(<=1$ year $)=\mathrm{LT}$ credits $(>1$ year $)$

(c)

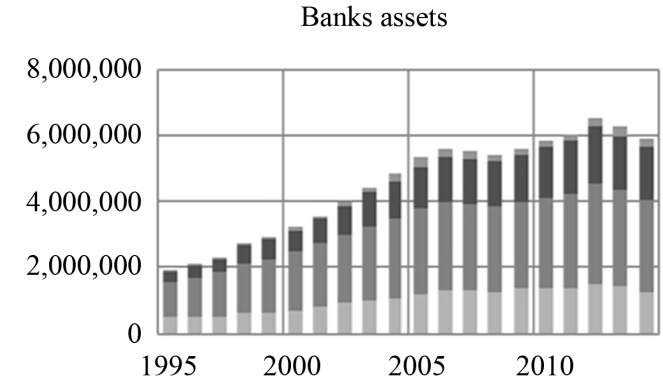

$\llbracket$ Interbank deposits $\square$ Loans $\square$ Securities $₫$ Other assets

(b)

LT households credits, by purpose (total outstanding volume)

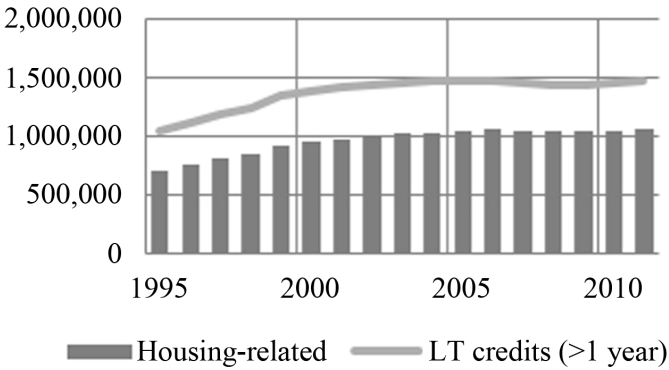

(d)

Figure 2. Germany: households credits and banking intermediation (millions EUR, source OCDE).

Total households credits and credit portfolios (including households) in banks balance sheets

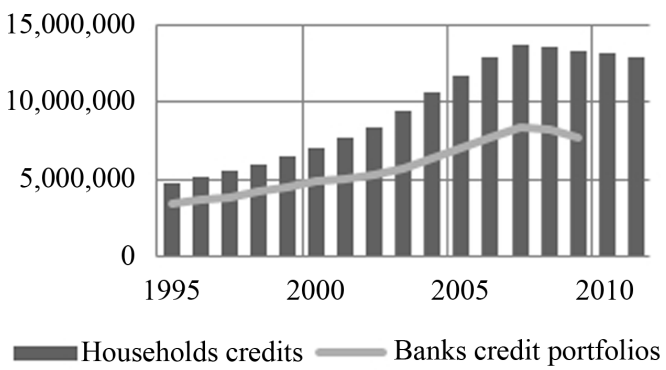

(a)

Households credits, by term (total outstanding volume)

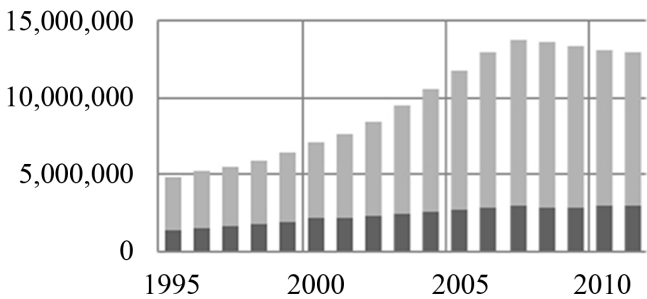

- ST credits $(<=1$ year $) \square \mathrm{LT}$ credits $(>1$ year $)$

(c)

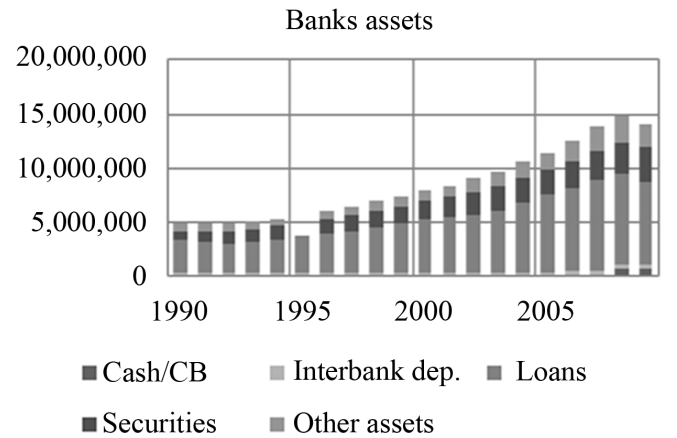

(b)

LT households credits, by purpose (total outstanding volume)

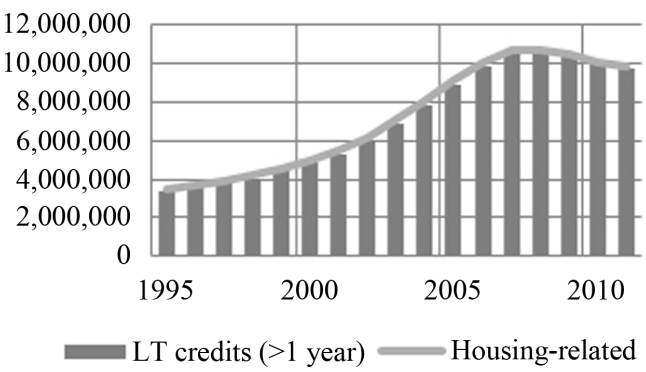

(d)

Figure 3. United States: households credits and banking intermediation (millions USD, source OCDE). 
sitive to default risk (usually less than $10 \%$ of short-term credits, significant proportion of non-housing related credits). In the "American" model, they are more sensitive (about one-fourth of short-term credits, almost no diversification of long-term credits). Moreover, while in France and Germany variable rate loans usually account for about 15\% of new loans [9], in the United States these loans represent nearly the half of total mortgage loans [10]. Therefore, it is necessary to consider households credits, in and outside of the banking system, and the related interest rate risk sharing in formulating the intermediation model.

Furthermore, the features of financial intermediation determine how the Central bank takes the financial stability objective into account. The empirical results of [11] regarding the implementation of the Taylor rule by the ECB, FED and BOE suggest that there are once again two distinct schemes. In the United States and United Kingdom, where the proportion of households credits in banking intermediation is high, there is a strong link between the output gap, households failures and financial stability. The Central bank implements a simple (United States) or augmented with the sole credit spread (United Kingdom) Taylor rule. In the Eurozone, the weight of households credits is lower and thus the relationship between the output gap and financial stability is less strong. The tests validate an augmented Taylor rule, with a broad financial conditions indicator. Thus in the model the Central bank uses a Taylor-type rule with a financial stability term which coefficient can be zero.

The second and third key characteristic of the model are related to the complexity of the relationship between prices and funding supply volumes in times of financial strains [8] [9]. During the global crisis, in the first stage, in the interbank market but also in credit and securities markets there is simultaneously a positive shock on the cost of capital and reduction of its availability. During the second stage of the crisis, in credit and securities markets, volumes keep decreasing in the context of a lasting dysfunction of the interbank market. In the model, funding supply volumes in times of financial strains are, thus, negatively linked to prices, and positively linked to the persistence of an excess interbank funding demand.

Finally, stylized facts bring up three key features. There are two types of financial intermediation schemes concerning households credit. In the first scheme, households credits largely exceed total bank credits and are sensitive to default risk due to their composition. In the second type, their volume is lower, and their composition makes them less sensitive to default risk. In the first case, Central banks would rather conduct a simple Taylor rule, and in the second case, an augmented Taylor rule with a financial conditions indicator. Finally, in times of financial strains, all market segments can be characterized by a rise in prices simultaneously with a reduction in the availability of funding supply, enhanced by the persistent dysfunction of the interbank market.

\section{Survey}

Our purpose is to incorporate these mechanisms in a simple theoretical model of financial intermediation with a central bank, in order to describe a crisis generated by a shock on households credits failures. To this end, we introduce a distinction for credit markets between households and firms from the perspective of borrowers, and between banks and non-monetary financial institutions (NMFI) from the perspective of lenders. Thus, it is possible to take into account the roles of both households credits and shadow banking [12].

Households credits defaults are specifically sensitive to the output gap and interest rate risk [5] [6]. The default rate also depends on the modalities of financial intermediation [7] [13]: securitized loans are subject to a higher default risk than other credits. As regards the ultimate origin of the defaults shock, formalization must take into consideration both private agents behaviors within the intermediation model and monetary policy decisions. The literature relating to the 2007 crisis illustrates this dual causality. On the one hand, the modalities of financial intermediation have dramatically changed, due to "supply shocks" on monetary aggregates. These shocks are related to the behavior of commercial banks [14] in the context of an increased liquidity resulting from international balance of payments imbalances. On the other hand, part of the recent empirical literature, based on the theory of the credit channel transmission of monetary policy [15], calls into question changes in monetary policies. Thus, in our model, the defaults shock is triggered by a rise in the official interest rate. This decision leads to a dysfunction of the whole financial system if households and firms funding is already fragile, respectively as regards interest rate risk on outstanding loans and funding supply features.

The sequence of the model then presents the main stylized facts of the global crisis: the defaults shock on securitized loans triggers a deterioration of financing conditions in the corresponding complex securities market and, therefore, the interbank market [16]. Finally, the whole financing system is disrupted [1] by a decrease in funding supply and increase in the cost of capital [8]. This unusual configuration of funding supply is, however, fully in line with the principles of the credit (in case of a positive shock on the cost of capital, credit availability 
is reduced by the enhancement of informational asymmetries between lenders and borrowers [15]), and risktaking (credit availability is reduced by the increasing risk aversion of lenders [17]) channels of monetary policy transmission. Alternatively, this setting of funding supply could be seen as a generalization of the non-mo- notonic supply function of Stiglitz \& Weiss, although this function does not allow determining the excess demand resulting from a shock on prices since market equilibrium is not at the intersection of supply and demand curves. In our model, credit and securities markets are affected at various degrees [18] [19] by the cost of capital and funding supply shocks. The magnitude of these dysfunctions determines the content and extent of fiscal and monetary policy measures, both directly, and via the resulting output gap [20] [21].

Regarding the Central bank, the model must meet a specific constraint: the monetary policy rule has to describe decisions in both crises and non-crises times. A Taylor-type rule [22] augmented with a financial conditions indicator can achieve part of this objective. Despite of controversy, the empirical literature usually shows its relevance [11] [23]. There are two possible settings of the financial conditions indicator. The first possibility is to use volume indicators, such as credit indicators. The second possibility is to use asset prices or cost of capital indicators, such as credit spreads ("adjusted" Taylor rule [3]). In our model, the official interest rate is determined by a Taylor-type rule augmented with a price indicator of financial conditions, while volumes are taken into account in the rest of the monetary policy rule. Since the initial shock is transmitted through the interbank market, the financial conditions indicator is the interbank spread [16] [24].

In the formulation of monetary policy, the idea of a renewed interest of volumes and not only prices variables is quite extensively shared in the recent literature [25]. In our model, the formalization of an unconventional monetary policy with its usual three instruments (interest rates, liquidity injections and assets purchases [26]) cannot be limited to an augmented Taylor rule. For these two reasons, we include the separate expression of the amounts of liquidity injections and assets purchases in the monetary policy rule.

The model, therefore, includes the following elements: concerning the Central bank, the augmented Taylortype rule is accompanied with the conditions of intervention as regards the two other possible instruments of monetary policy (liquidity injections in the interbank market and assets purchases). The shock is triggered by an increase in households credits defaults, which magnitude and consequences depend on the features of the intermediation scheme, i.e. the sharing out of households credits (alternatively held by banks or non-monetary institutions) and firms funding (in the form of securities or credit).

\section{The Model: Agents and Financial System}

\subsection{The Intermediation Chain}

There are two types of assets: credit and securities. Credit markets correspond to $C 1$ (interbank market) and $C 2$ (credit to non-financial agents). Primary securities markets correspond to E0 (government bonds), E1 (securities issued by firms) and E2 (complex securities issued by NMFI).

The funding of the agents in the model is described by the rows of Table 1. For the government, this funding is in the form of bonds. For households, it is in the form of loans, held either by banks (in proportion $h_{b}$ of banks credits portfolios) or NMFI. These loans are supposed to be fixed rates when they are held by banks $\left(C 2_{b}\right)$, and variable rates when they are held by NMFI $\left(C 2_{n b}\right)$. The funding of firms is in the form of bank credit (in proportion $\left(1-h_{b}\right)$ of banks credits portfolios) and securities. As regards the financial sector, the short-term funding of banks is in the form of interbank credit, and the funding of NMFI in the form of complex securities.

Table 1. Funding of economic agents.

E0 Government bonds $E 1$ Securities $\quad E 2$ Complex securities $C 1$ Interbank credit $C 2_{b}$ Credit (banks) $C 2_{n b}$ Credit (NMFI)

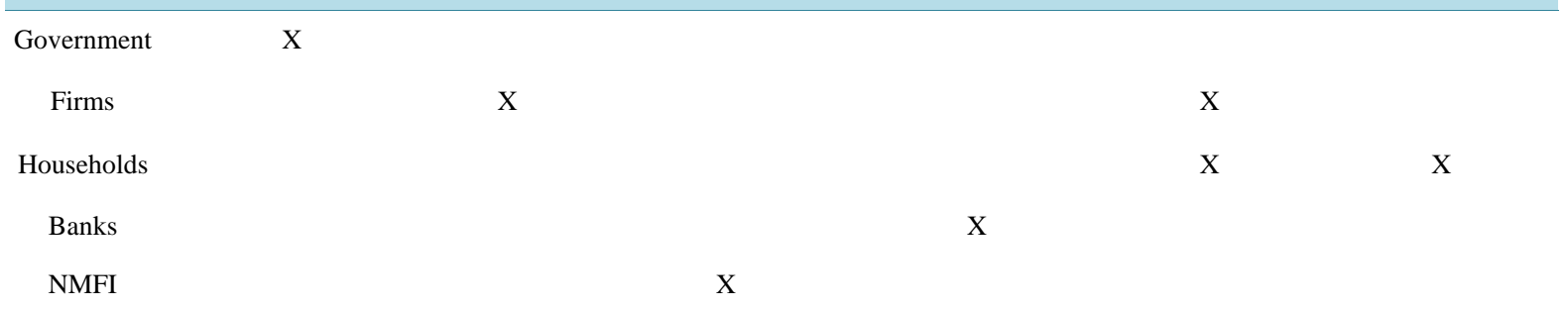


The intermediation model is thus characterized by the share of households in bank loans $h_{b}$, the share of households credits held by NMFI relative to total outstanding credits to non-financial agents $C 2_{n b} /\left(C 2_{b}+C 2_{n b}\right)$, and the share of securities funding of firms $E 1 /\left[\left(1-h_{b}\right) C 2_{b}+E 1\right]$.

\subsection{Sequence of the Model}

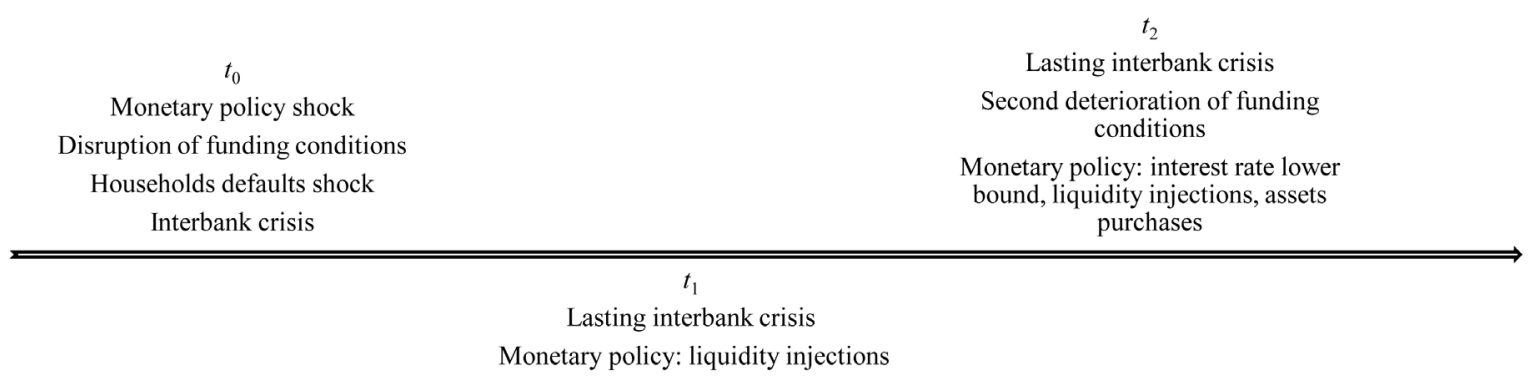

All the markets are originally in equilibrium. In $t_{0}$, a positive monetary policy (official interest rate) shock happens. This results in an increase in households variable rate loans defaults: on the one hand the cost of variable rate loans rises, and on the other hand the disruption of funding conditions results in a negative output gap, which also affects households repayment capacity.

The defaults shock causes a risk premium and excess funding demand shock in complex securities and interbank markets. In $t_{1}$, the Central bank injects the amount of liquidity corresponding to the excess interbank funding demand (in comparison to private supply). In $t_{2}$, credit and securities markets undergo a second deterioration of their funding conditions, because of the persistence of this excess interbank funding demand with regards to private supply. The Central bank continues liquidity injections and uses its other two instruments: interest rate cuts, and if the lower bound is reached, assets purchases in securities markets.

\subsection{Credit Markets}

Each asset is characterized by funding conditions described by the risk premium and excess funding demand. The risk premium $\pi$ is defined as the difference between the nominal yield $r$ and policy rate $r_{C B}$ :

$$
r=r_{C B}+\pi
$$

In interbank (C1) and non-financial agents credit markets $(C 2)$, the excess funding demand $C M_{i}$ is measured by the difference between credit demand $D C_{i}$ and supply $S C_{i}$. It increases when credit interest rates raise, under two conditions. First, any increase in this rate deteriorates expected bank yields by increasing the probability of default on credit portfolios, which results in a decreasing aggregate supply function; and secondly this function is steeper than the demand function. Periods of low (high) interest rates are thus characterized by an excess credit supply (demand) [8] [15] [17]. The corresponding excess funding demand function $C M_{i}$ is as follows:

$$
\begin{gathered}
C M_{i}=D_{C i}\left(r_{C i}\right)-S_{C i}\left(r_{C i}\right) \\
\frac{\partial D_{C i}}{\partial r_{C i}}<0, \frac{\partial S_{C i}}{\partial r_{C i}}<0,\left|\frac{\partial D_{C i}}{\partial r_{C i}}\right|<\left|\frac{\partial S_{C i}}{\partial r_{C i}}\right|
\end{gathered}
$$

The interbank supply and demand functions are assumed to be linear:

$$
\begin{gathered}
S_{C 1}=-c r_{C 1}+d, c>0, d>0 \\
D_{C 1}=-a r_{C 1}+b, c>a>0 \text { et } d>b>0 \\
C M_{1}=(c-a) r_{C 1}+(b-d)
\end{gathered}
$$

\subsection{Private Sector Securities Markets}

In securities markets issued by firms $(E 1)$ and NMFI (E2), the excess funding demand $E M_{i}$ is measured by the difference between securities supply $S_{E i}$ and demand $D_{E i}$, for a given nominal yield $r_{E i}$. As in credit markets, the demand function (funding supply) is assumed to be both decreasing and steeper than the supply function. Con- 
sequently, a shock on the cost of capital results in a positive excess funding demand:

$$
\begin{gathered}
E M_{i}=S_{E i}\left(r_{E i}\right)-D_{E i}\left(r_{E i}\right) \\
\frac{\partial D_{E i}}{\partial r_{E i}}<0, \frac{\partial S_{E i}}{\partial r_{E i}}<0,\left|\frac{\partial S_{E i}}{\partial r_{E i}}\right|<\left|\frac{\partial D_{E i}}{\partial r_{E i}}\right|
\end{gathered}
$$

In Section 4, the excess funding demand functions in credit and securities markets are supplemented by the consideration of two additional elements. First, the impact of official interest rates decreases and rises decisions is asymmetrical; secondly, the persistent insufficient private funding in the interbank market causes an increase in households and firms excess funding demands.

\subsection{Government Bonds Market}

Bonds supply $S_{E 0}$ in the primary market depends on an exogenous component $\bar{S}$ (structural level) and the amount of support measures to the sectors that are affected by the shock on funding conditions. The different types of agents are all the more affected than their excess funding demand is important [20] [21]. So support measures are allocated in proportion to excess funding demands:

$$
S_{E 0}=\bar{S}+\alpha\left[\left(D_{C 1}-S_{C 1}\right)+\left(D_{C 2}-S_{C 2}\right)+\left(S_{E 1}-D_{E 1}\right)+\left(S_{E 2}-D_{E 2}\right)\right], \alpha>0
$$

Consequently, when a shock arises, government securities supply is increased by the amount of support measures to the financial sector (excess funding demand in interbank and complex securities markets), households and firms (excess funding demand in credit and securities markets).

The government bonds demand $D_{E 0}$ depends positively on an exogenous component $\bar{D}$ (structural level), negatively on the current fiscal deficit $S_{E 0}$, and positively on flight to quality effects generated by excess funding demands in other markets.

$$
D_{E 0}=\bar{D}-\beta S_{E 0}+\gamma\left[\left(D_{C 1}-S_{C 1}\right)+\left(D_{C 2}-S_{C 2}\right)+\left(S_{E 1}-D_{E 1}\right)+\left(S_{E 2}-D_{E 2}\right)\right], \beta>0, \gamma>0
$$

The excess funding demand of government bonds is then the following:

$$
S_{E 0}-D_{E 0}=(1+\beta) \bar{S}-\bar{D}+(\alpha(1+\beta)-\gamma)\left[\left(D_{C 1}-S_{C 1}\right)+\left(D_{C 2}-S_{C 2}\right)+\left(S_{E 1}-D_{E 1}\right)+\left(S_{E 2}-D_{E 2}\right)\right]
$$

For a given excess funding demand in private sector assets markets, the government bonds market, therefore, is characterized by an excess funding demand which is positively linked to $\alpha$ (fiscal policy activism) and $\beta$ (sensitivity of economic agents to fiscal deficit), and negatively linked to $\gamma$ (flight to quality effects).

\subsection{Monetary Policy Rule}

The monetary policy rule consists of three instruments: the official interest rate, liquidity injections, and assets purchases. The official interest rate follows an augmented Taylor-type rule:

$$
\left\{\begin{array}{l}
r_{B C T}=c t+\Pi+\mu_{\Pi}(\Pi-\Pi *)+\mu_{y}\left(y-y^{*}\right)-\mu_{C 1}\left(\pi_{C 1}-\pi_{C 1} *\right), \text { with } \mu_{\Pi}>0, \mu_{g}>0, \mu_{C 1} \geq 0 \\
r_{B C}=r_{B C T} \text { if } r_{B C T} \geq \underline{r_{B C}} \\
r_{B C}=\underline{r_{B C}} \text { if } r_{B C T}<\underline{r_{B C}}
\end{array}\right.
$$

The endogenous variable is the official (instrument) and not short-term interbank interest rate (target), in order to isolate the interbank risk in the last term. The official interest rate depends on a constant representing the neutral real interest rate, the inflation level $\Pi$, the inflation gap $\left(\Pi-\Pi^{*}\right)$, the output gap $\left(y-y^{*}\right)$, and the interbank risk premium gap $\left(\pi-\pi^{*}\right)$ [16] [24]. The coefficient associated with $\left(\pi-\pi^{*}\right)$ can be zero: when the intermediation model is characterized by a significant weight of variable rate households credits, consideration of the output gap will de facto decrease financial strains. Finally, the official interest rate cannot be lower than its bound $r_{B C}$.

The other two instruments of monetary policy concern the excess funding demand in the different market segments. The Central bank meets a positive excess funding demand by liquidity injections (in the interbank market) and assets purchases (in securities markets). The intervention thresholds are the following: 


$$
\begin{cases}C M_{1}<\overline{C M_{1}}, & \overline{C M_{1}}=0 \\ E M_{0}<\overline{E M_{0}}, & \overline{E M_{0}}<0 \\ E M_{i}<\overline{E M_{i}}, & \overline{E M_{i}}>0, \quad i=1,2\end{cases}
$$

The thresholds are, respectively, zero in the interbank market, which should never be rationed; negative in the government bonds market, which must be characterized by an excess demand; and positive for other securities markets. Consequently, the amount $X$ of a possible liquidity injection corresponds to the amount of the interbank excess funding demand. The possible amount $Z_{i}$ of assets purchases corresponds to the difference between the excess funding demand and threshold of the Central bank. Thus, the complete monetary policy rule is as follows:

$$
\begin{aligned}
r_{B C} & =\left\{\begin{array}{ll}
r_{B C T} & \text { if } r_{B C T}>\underline{r_{B C}} \\
\frac{r_{B C}}{\overline{r_{B C}}} & \text { if } r_{B C T} \leq \underline{r_{B C}}
\end{array}\right\} \\
X & = \begin{cases}C M_{1}-\overline{C M_{1}} & \text { if } C M_{1 t-1}>\overline{C M_{1}} \\
0 & \text { otherwise }\end{cases} \\
Z_{i} & = \begin{cases}E M_{i}-\overline{E M_{i}} & \text { if } r_{B C T}=\underline{r_{B C}}, E M_{i t-1}>\overline{E M_{i}}, E M_{i t-2}>\overline{E M_{i}}, i=(0,2) \\
0 & \text { otherwise }\end{cases}
\end{aligned}
$$

The official interest rate corresponds to the Taylor rate if its determination leads to a higher value than the lower bound and to this lower bound otherwise. Liquidity injections and assets purchases are only conducted when the excess funding demand exceeds the Central bank threshold. In this case, they are conducted in order to reduce this level to the threshold. This measure occurs systematically at the next period in the interbank market. By contrast, it takes place after two consecutive periods of excess funding demand in securities markets, only if the policy interest rate is at the lower bound. Finally, as regards the official interest rate, the Central bank cannot take two immediately consecutive decisions in opposite directions.

\section{The Model: Defaults Shock and Monetary Policy}

\subsection{Defaults Shock and Complex Assets Markets $\left(t_{0}\right)$}

Consideration of an endogenous default rate of households is one of the fundamental assumptions of the model. Defaults on households credits are related to interest rate risk. The interest rate risk associated with bank credits is fully borne by banks (fixed rate loans), while the interest rate risk associated with credits held by NMFI is borne by households (variable rate loans). Defaults on households credits are also related to the output gap. Regarding firms funding, the initial monetary policy shock reduces the availability of both credit and securities funding [18]. This reduced availability is then the weighted sum, depending on the shares of credit and securities in firms funding, of excess funding demands in credit and securities markets. This results in a negative output gap [20] [21], which is the second determinant of the default function of households on their variable rate loans.

Let $\lambda_{b}$ and $\lambda_{n b}$ denote default rates on households credits, respectively held by banks and NMFI. $\lambda_{b}$ is supposed to be constant. $\lambda_{n b}$ depends positively on official interest rates variations and the output gap [5] [6]:

$$
\Delta \lambda_{n b}=\zeta \Delta r_{C B}+\eta \Delta y, \zeta, \eta>0
$$

The shock is triggered by an increase in the official interest rate $\left(\Delta r_{C B}>0\right)$. Since the output gap is proportional to the weighted sum of variations in excess funding demands of firms in credit and securities markets, we obtain the following form:

$$
\Delta \lambda_{n b}=\zeta \Delta r_{C B}+\frac{\eta}{\left(1-h_{b}\right)\left(C 2_{b}\right)+E 1}\left(E 1 \frac{\partial E M_{1}}{\partial r_{C B}}+\left(1-h_{b}\right)\left(C 2_{b}\right) \frac{\partial C M_{2}}{\partial r_{C B}}\right)
$$

NMFI, which hold variable rates households credits, are funded by selling complex securities. In return, the remuneration of these securities depends on the interests flows on portfolios of variable rates credits. Therefore, the rise in the corresponding default rate $\lambda_{n b}$ entails a rise in the risk premium $\pi_{E 2}$ in complex securities market, 
which is assumed to be equivalent:

$$
\Delta \pi_{E 2}=\Delta \lambda_{n b}
$$

Considering the securities supply and demand functions given by Equation (4), it results in a positive excess funding demand in the complex securities market.

\subsection{Transmission to the Interbank Market and Liquidity Injections $\left(t_{1}\right)$}

The shock on funding conditions in the complex securities market is transmitted to the interbank market. This results in a simultaneous rise in the interbank risk premium $\left(\Delta \pi_{C 1}>0\right)$ and excess funding demand $\left(\Delta C M_{1}>0\right)$. The variation of the interbank risk premium depends on the variation of the risk premium in the complex securities market (Equations (8) and (9)), and the size of this market compared to total outstanding credits:

$$
\Delta \pi_{C 1}=\Delta \pi_{E 2}\left(\frac{C 2_{n b}}{C 2_{b}+C 2_{n b}}\right)
$$

which is equivalent to the following total variation of the interbank rate, using Equations (8) and (9):

$$
\begin{gathered}
\Delta r_{C 1}=\Delta r_{B C}+\Delta \pi_{E 2}\left(\frac{C 2_{n b}}{C 2_{b}+C 2_{n b}}\right) \\
\Delta r_{C 1}=\Delta r_{B C}+\left[\zeta \Delta r_{C B}+\frac{\eta}{\left(1-h_{b}\right)\left(C 2_{b}\right)+E 1}\left(E 1 \frac{\partial E M_{1}}{\partial r_{C B}}+\left(1-h_{b}\right)\left(C 2_{b}\right) \frac{\partial C M_{2}}{\partial r_{C B}}\right)\right]\left(\frac{C 2_{n b}}{C 2_{b}+C 2_{n b}}\right)
\end{gathered}
$$

Equation (12) describes the excess interbank funding demand (in comparison to private supply):

$$
C M_{1 \cdot t 1}=(c-a)\left[\Delta r_{B C}+\Delta \pi_{E 2}\left(\frac{C 2_{n b}}{C 2_{b}+C 2_{n b}}\right)\right]
$$

The Central bank responds by injecting the corresponding amount of liquidity, according to the monetary policy rule given by Equation (7), i.e. $X_{t 1}=C M_{1 \cdot t 1}$. Since the Central bank cannot take two immediately consecutive interest rates decisions in opposite directions, liquidity injections are the only available instrument in $t_{1}$. The excess funding demand in securities markets does not either generate an intervention, since the Central bank can conduct assets purchases only after the second consecutive period of rationing.

\subsection{Interest Rate Lower Bound and Liquidity Injections $\left(t_{2}\right)$}

In $t_{2}$, the default rate on households variable rates credits, given by Equation (8), is assumed to be unchanged. Consequently, risk premia in complex securities (Equation (9)) and interbank (Equation (10)) markets are also assumed to be unchanged. As regards monetary policy, the interest rate cut is possible, considering the persistent negative output gap and financial strains (interbank risk premium gap, Equation (6)), since this decision is not immediately following the initial interest rate rise.

The remainder of this section deals with the case where the interest rate is taken to its lower bound, in which the central bank is likely to conduct assets purchases. According to Equation (11), the difference between the interbank interest rate and the initial equilibrium value can be written as follows:

$$
\begin{gathered}
\Delta r_{C 1 t 1}+\Delta r_{C 1 t 2}=\left(\underline{r_{B C}}-r_{B C t 0}\right)+\Delta \pi_{C 1 t 1} \\
\Delta r_{C 1 t 1}+\Delta r_{C 1 t 2}=\left(r_{B C}-r_{B C t 0}\right)+\Delta \pi_{E 2}\left(\frac{C 2_{n b}}{C 2_{b}+C 2_{n b}}\right)
\end{gathered}
$$

Equation (14) describes the interbank excess funding demand. As in $t_{1}$, it is met by a Central bank liquidity injection of the same amount, that is $X_{t 2}=C M_{1+2}$.

$$
C M_{1 t 2}=(c-a)\left[\left(\underline{r_{B C}}-r_{B C t 0}\right)+\Delta \pi_{E 2}\left(\frac{C 2_{n b}}{C 2_{b}+C 2_{n b}}\right)\right]
$$

In the other private sector asset markets (credit and securities), the excess funding demand is aggravated by 
the persistence of an insufficient interbank credit supply, because of the interbank rationing channel:

$$
\left\{\begin{array}{l}
\Delta C M_{2}=v_{C 2} C M_{1} \\
\Delta E M_{i}=v_{E i} C M_{1} \quad i=1,2
\end{array}\right.
$$

Coefficients $v$ represents the effect of the interbank rationing channel in each market segment. Considering that decreases in official interest rates are passed on to interest rates on households and firms credits to a very limited extent in comparison with rises, the latter are assumed to be unchanged compared to $t_{1}$. Therefore, the excess funding demand corresponds to the sum of the value of $t_{1}$, and an additional component described above, that is:

$$
\left\{\begin{array}{l}
C M_{2}=\frac{\partial C M_{2}}{\partial r_{C B}}+v_{C 2} C M_{1} \\
E M_{i}=\frac{\partial E M_{i}}{\partial r_{C B}}+v_{E i} C M_{1} \quad i=1,2
\end{array}\right.
$$

\subsection{Assets Purchases ( $\left.t_{2}\right)$}

In $t_{2}$, in addition to liquidity injections and the use of the lower bound on interest rates, the Central bank conducts assets purchases, in order to reduce the gap between funding supply and demand to its desired threshold level (Equation (7)). In the case of government bonds, using Equations (5) and (15), the excess funding demand takes the following form:

$$
S_{E 0}-D_{E 0}=(1+\beta) \bar{S}-\bar{D}+(\alpha(1+\beta)-\gamma)\left[C M_{1}+\left(\frac{\partial C M_{2}}{\partial r_{C B}}+v_{C 2} C M_{1}\right)+\left(\sum_{i=1}^{2} \frac{\partial E M_{i}}{\partial r_{C B}}+v_{E i} C M_{1}\right)\right]
$$

If this difference is superior to the threshold level, the Central bank will conduct assets purchases of the corresponding amount, that is:

$$
Z_{0}=\left(S_{E 0}-D_{E 0}\right)-\overline{E M_{0}}
$$

In private sector securities markets, the same principle applies. If excess funding supply is superior to the threshold level, the Central bank purchases assets as long as this value is not reached. Using Equations (14) and (15), we get:

$$
\begin{gathered}
Z_{i}=\left(S_{E i}-D_{E i}\right)-\overline{E M_{i}}, i=1,2 \\
Z_{i}=\left(\frac{\partial E M_{i}}{\partial r_{C B}}+v_{E i} C M_{1}\right)-\overline{E M_{i}} \\
Z_{i}=\frac{\partial E M_{i}}{\partial r_{C B}}+v_{E i}(c-a)\left[\left(\underline{r_{B C}}-r_{B C t 0}\right)+\Delta \pi_{E 2}\left(\frac{C 2_{n b}}{C 2_{b}+C 2_{n b}}\right)\right]-\overline{E M_{i}}
\end{gathered}
$$

The decisions of the Central bank in $t_{2}$ are thus the following, the value of the interbank excess funding demand $C M_{1+2}$ being given by Equation (14):

$$
\left\{\begin{array}{l}
r_{B C t 2}=\underline{r_{B C}} \\
X_{t 2}=C M_{1 t 2}-\overline{C M_{1}} \\
Z_{0 t 2}=(1+\beta) \bar{S}-\bar{D}+(\alpha(1+\beta)-\gamma)\left[C M_{1}+\left(\frac{\partial C M_{2}}{\partial r_{C B}}+v_{C 2} C M_{1}\right)+\left(\sum_{i=1}^{2} \frac{\partial E M_{i}}{\partial r_{C B}}+v_{E i} C M_{1}\right)\right]-\overline{E M_{0}} \\
Z_{i t 2}=\left(\frac{\partial E M_{i}}{\partial r_{C B}}+v_{E i} C M_{1}\right)-\overline{E M_{i}}, i=1,2
\end{array}\right.
$$

The persistent deterioration of interbank funding conditions resulting from the initial shock on households credits causes that of all other market segments and, therefore, determines the terms of monetary policy. At the beginning of the crisis, since the Central bank wants the interbank market to remain in equilibrium, it is forced 
to conduct the corresponding liquidity injection. In the second stage of the crisis, the Central bank uses the whole range of monetary policy tools. If interbank funding conditions remain largely deteriorated, the Taylortype official interest rate is inferior to the lower bound. Thus, the interest rate is set at this lower bound level. Then assets purchases are conducted under the condition that the excess funding demand is persistent. In the case of private sector securities, the corresponding amount positively depends on the interbank rationing channel effect. In the case of government bonds, it depends also on the structural component of government bonds demand, government choices (structural fiscal deficit, propensity to support economic activity), and private choices (sensitivity of government bonds demand to fiscal deficit, and sensitivity to financial strains in other segments of the financial system).

\section{Concluding Remarks}

The contribution of this paper is threefold. Firstly, the model takes into account the growing importance of households credits, within banks and total outstanding credits portfolios. Secondly, it proposes a transmission sequence of a shock on households credits portfolios to the whole financing system via the interbank market. The extent and conditions of transmission of the initial shock depend on the features of financial intermediation, i.e. the relative importance of households credits and the structure of firms funding. Thirdly, the Central bank monetary policy rule captures decisions in both non-crises times, with the Taylor-type rule; and crises times, with the intervention thresholds associated with liquidity injections and assets purchases, and the corresponding restrictive conditions. Finally, the model takes into account the main features of funding supply in times of financial strains, that is to say a complex relationship between prices and funding supply volumes and the intervention of the central bank in the context of non-standard monetary policies.

\section{References}

[1] Freixas, X. and Jorge, J. (2008) The Role of Interbank Markets in Monetary Policy: A Model with Rationing. Journal of Money, Credit and Banking, 40, 1151-1176. http://dx.doi.org/10.1111/j.1538-4616.2008.00152.x

[2] Stein, J.C. (2012) Monetary Policy as Financial Stability Regulation. The Quarterly Journal of Economics, 127, 57-95. http://dx.doi.org/10.1093/qje/qjr054

[3] Cúrdia, V. and Woodford, M. (2010) Conventional and Unconventional Monetary Policy. Federal Reserve Bank of St. Louis Review, 92, 229-264.

[4] Gertler, M. and Karadi, P. (2011) A Model of Unconventional Monetary Policy. Journal of Monetary Economics, 58, 17-34. http://dx.doi.org/10.1016/j.jmoneco.2010.10.004

[5] Beck, T., Buyukkarabacak, B., Rioja, F. and Valev, N. (2008) Who Gets the Credit? And Does It Matter? Household vs. Firm Lending across Countries. World Bank Policy Research Working Paper, No. 4661.

[6] Benford, J. and Nier, E. (2007) Monitoring Cyclicality of Basel II Capital Requirements. Bank of England Financial Stability Paper, No. 3.

[7] Purnanandam, A. (2010) Originate-to-Distribute Model and the Subprime Mortgage Crisis. The Review of Financial Studies, 24, 1881-1915. http://dx.doi.org/10.1093/rfs/hhq106

[8] Krishnamurthy, A. (2010) How Debt Markets Have Malfunctioned in the Crisis. Journal of Economic Perspectives, 24, 3-28. http://dx.doi.org/10.1257/jep.24.1.3

[9] ECB (2009) Monetary Policy and Loan Supply in the Euro Area. ECB Monthly Bulletin, 63-80.

[10] Moench, E., Vickery, J. and Aragon, D. (2010) Why Is the Market Share of Adjustable-Rate Mortgages So Low? Federal Reserve Bank of New York Current Issues in Economics and Finance, 16, 1-11.

[11] Castro, V. (2011) Can Central Banks’ Monetary Policy Be Described by a Linear (Augmented) Taylor Rule or by a Nonlinear Rule? Journal of Financial Stability, 7, 228-246. http://dx.doi.org/10.1016/j.jfs.2010.06.002

[12] Adrian, T. and Shin, H.S. (2010) The Changing Nature of Financial Intermediation and the Financial Crisis of 20072009. Annual Review of Economics, 2, 603-618. http://dx.doi.org/10.1146/annurev.economics.102308.124420

[13] Maddaloni, A. and Peydró, J.L. (2011) Bank Risk-Taking, Securitization, Supervision, and Low Interest Rates: Evidence from the Euro-Area and the U.S. Lending Standards. Review of Financial Studies, 24, 2121-2165. http://dx.doi.org/10.1093/rfs/hhr015

[14] Goodhart, C.A.E. (2009) Whatever Became of the Monetary Aggregates? In: Hammond, G., Ravi, S.M. and Prasad, E., Eds., Monetary Policy Frameworks for Emerging Markets, Edward Elgar Publishing, London, 59-68.

[15] Bernanke, B. and Gertler, M. (1995) Inside the Black Box: The Credit Channel of Monetary Policy Transmission. Na- 
tional Bureau of Economic Research Working Paper, No. 5146.

[16] Wu, T. (2011) The US Money Market and the Term Auction Facility in the Financial Crisis of 2007-2009. Review of Economics and Statistics, 93, 617-631. http://dx.doi.org/10.1162/REST_a_00083

[17] Gambacorta, L. (2009) Monetary Policy and the Risk-Taking Channel. BIS Quarterly Review, 400, 43-53.

[18] Cardarelli, R., Elekdag, S. and Lall, S. (2011) Financial Stress and Economic Contractions. Journal of Financial Stability, 7, 78-97. http://dx.doi.org/10.1016/j.jfs.2010.01.005

[19] Cornett, M., McNutt, J.J., Strahan, P. and Tehranian, H. (2011) Liquidity Risk Management and Credit Supply in the Financial Crisis. Journal of Financial Economics, 101, 297-312. http://dx.doi.org/10.1016/j.jfineco.2011.03.001

[20] Gerali, A., Neri, S., Sessa, L. and Signoretti, F. (2010) Credit and Banking in a DSGE Model of the Euro Area. Journal of Money, Credit and Banking, 42, 107-141. http://dx.doi.org/10.1111/j.1538-4616.2010.00331.x

[21] Helbling, T., Huidrom, R., AyhanKose, M. and Otrok, C. (2011) Do Credit Shocks Matter? A Global Perspective. European Economic Review, 55, 340-353. http://dx.doi.org/10.1016/j.euroecorev.2010.12.009

[22] Taylor, J.B. (1993) Discretion versus Policy Rules in Practice. Carnegie-Rochester Conference Series on Public Policy, 39, 195-214. http://dx.doi.org/10.1016/0167-2231(93)90009-L

[23] Hoffmann, A. (2013) Did the Fed and ECB React Asymmetrically with Respect to Asset Market Developments. Journal of Policy Modeling, 35, 197-211. http://dx.doi.org/10.1016/j.jpolmod.2012.09.005

[24] Williams, J.C. and Taylor, J.B. (2009) A Black Swan in the Money Market. National Bureau of Economic Research Working Paper, No. 13943.

[25] Cukierman, A. (2013) Monetary Policy and Institutions before, during, and after the Global Financial Crisis. Journal of Financial Stability, 9, 373-384. http://dx.doi.org/10.1016/j.jfs.2013.02.002

[26] Bernanke, B., Reinhart, V. and Sack, B. (2004) Monetary Policy Alternatives at the Zero Bound: An Empirical Assessment. Brookings Papers on Economic Activity, 2004, 1-100. http://dx.doi.org/10.1353/eca.2005.0002 
Scientific Research Publishing (SCIRP) is one of the largest Open Access journal publishers. It is currently publishing more than 200 open access, online, peer-reviewed journals covering a wide range of academic disciplines. SCIRP serves the worldwide academic communities and contributes to the progress and application of science with its publication.

Other selected journals from SCIRP are listed as below. Submit your manuscript to us via either submit@scirp.org or Online Submission Portal.
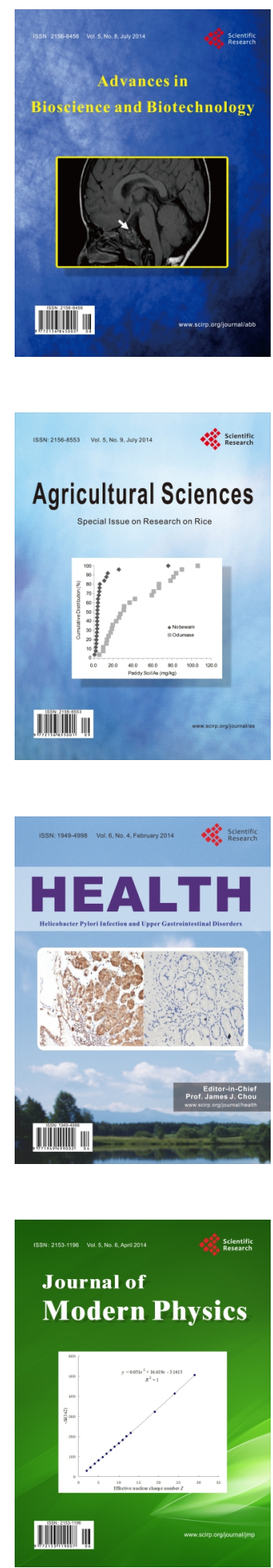
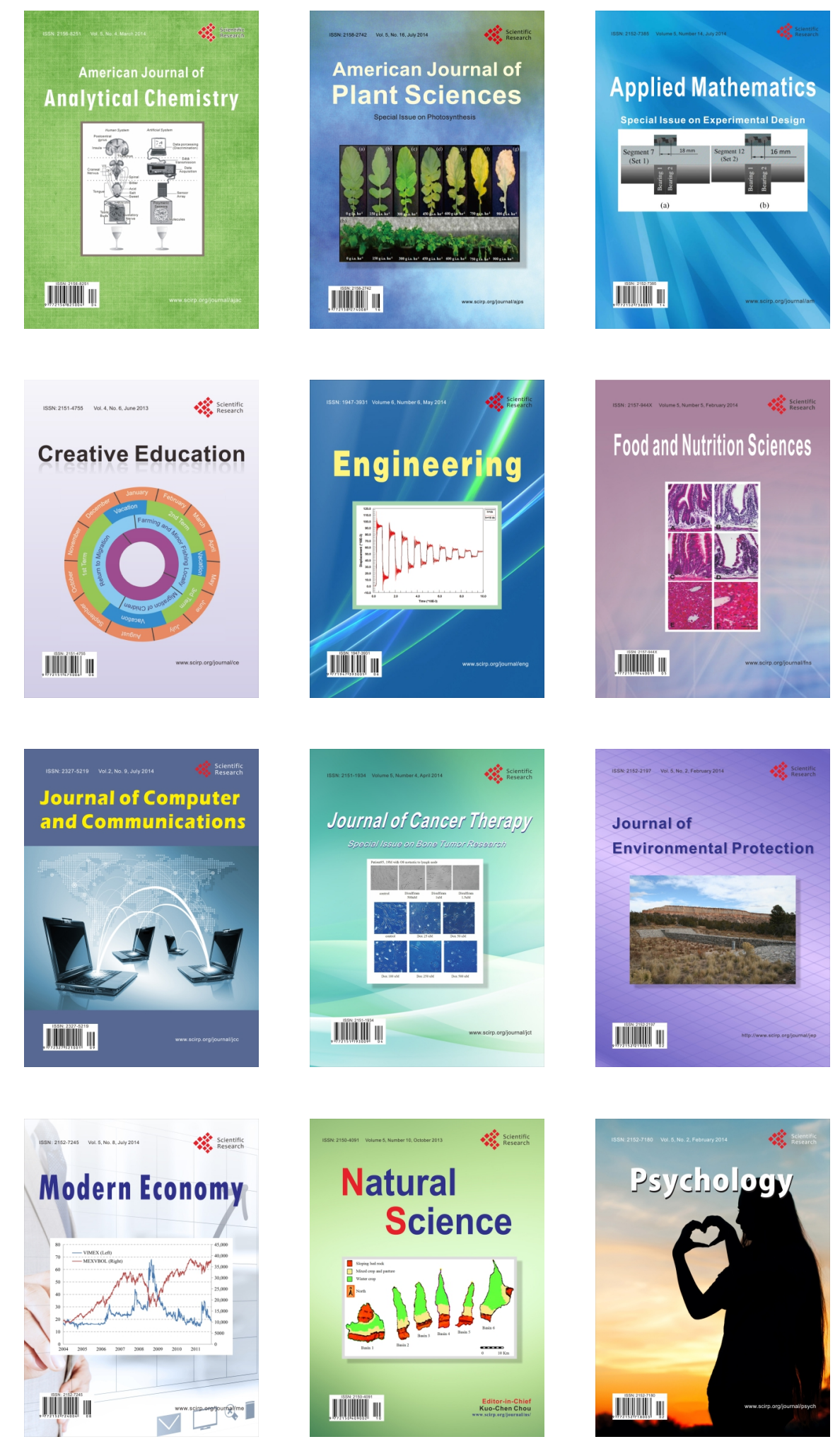